\title{
Accelerated Ageing Test in Maize: Pattern of Seed Deterioration
}

\author{
S. Kavitha ${ }^{1}$, C. Menaka ${ }^{1 \#}$, S. Srinivasan ${ }^{2}$ and A.Yuvaraja ${ }^{3}$ \\ ${ }^{1}$ Department of Seed Science and Technology \\ ${ }^{2}$ Department of Crop Physiology \\ ${ }^{3}$ Department of Millets \\ Tamil Nadu Agricultural University, Coimbatore 641003 , India
}

\begin{abstract}
The freshly harvested seeds of maize single cross hybrid TNAU maize hybrid CO 6 were kept under accelerated ageing condition by exposing the seeds to $40^{\circ} \mathrm{C}$ temperature and 100 per cent relative humidity in order to assess the physical, physiological and biochemical changes taking place during storage. This study revealed that minimum germination of 90 per cent as per the Indian Minimum Seed Certification Standards (IMSCS) was reached on $4^{\text {th }}$ day of accelerated ageing and reached 54 percent on $9^{\text {th }}$ day of accelerated ageing against the initial seed germination of 98 per cent. The moisture content was increased from 10.1 per cent to 15.9 per cent on $9^{\text {th }}$ day of accelerated ageing. The root length, shoot length, dry matter production, vigour index, $\alpha$-amylase, catalase, peroxidase activity and carbohydrate content were decreased. Whereas electrical conductivity of seed leachate and reducing sugars were increased, while advancing the period of accelerated ageing.
\end{abstract}

Key words : Maize, Accelerated ageing, Seed storage, Seed deterioration

Maize (Zea mays) is the most important cereal crops next to wheat and rice. It is a versatile crop grown over a range of agro climatic zones. The seed is rich in carbohydrate (75 per cent). It is utilized as food, feed, industrial raw material and for biofuel production. In India, it is cultivated in an area of 9.43 million hectares with a production of 24.35 million tonnes and an average productivity is $2.5 \mathrm{t} / \mathrm{ha}$. In Tamil Nadu, the crop is being cultivated in an area of 3.80 lakh hectares with a production of 2.24 million tonnes and an average productivity is $5.9 \mathrm{t} /$ ha. (www.indiastat.com, 2013 - 2014).

To cope with the current and future demand of the increasing population for the food grains, it is emphasized to reduce the loss of seeds during and after harvest. Seeds are stored for varying periods to ensure a proper and balanced public distribution throughout the year. Post harvest losses in India are estimated to be around 10 per cent of which the losses during storage alone are estimated to be 6 per cent (Singh and Satapathy, 2003). The study on physical, physiological and biochemical changes under accelerated ageing conditions will be helpful for better understanding the process of seed deterioration. The relative storability of a particular seed lot could be predicted through accelerated ageing by exposing the seeds to high temperature $\left(40^{\circ} \mathrm{C}\right)$ and relative humidity (100 per cent), which will be useful in retention or disposal of a particular variety or seed lot. Accelerated ageing has been developed as a self ageing technique. The accelerated ageing test has been used to estimate seed vigour and deterioration during storage (Delouche and Baskin, 1973). Keeping this in view, the present study was carried out in

*Corresponding author email: mesuy76@yahoo.co.in the Dept., of Seed Science and Technology, TNAU, Coimbatore.

\section{Material and Methods}

Genetically pure and freshly harvested seeds of maize (TNAU Maize Hybrid CO 6) were kept under accelerated ageing condition by exposing the seeds to $40^{\circ} \mathrm{C}$ temperature and 100 per cent relative humidity. The samples were drawn at daily interval from accelerated ageing condition and analyzed for physical, physiological and biochemical parameters. The following observations viz., seed moisture content, germination per cent, root length, shoot length, dry matter production, vigour index, electrical conductivity, $\alpha$-amylase, catalase, peroxidase activity, carbohydrate content and reducing sugars were made. The storability period was calculated based on the time taken to reach the germination as per the IMSCS. In order to assess the pattern of deterioration, the accelerated ageing was continued when seed reaches the germination of about 50 per cent.

\section{Results and Discussion}

The results indicated that the maize seed had low moisture content initially (10.1 per cent) and it was higher in 9 days (15.9 per cent) of accelerated ageing (Table 1). The possible reason could be due to continuous and slow supply of moisture to the seed which increased the moisture content of the seeds as the seeds are hydrophilic in nature. In the present investigation, deterioration in seed quality was associated with decrease in germination, seedling length, dry matter production and vigour index become evident with advancement of time in storage under accelerated ageing condition (Table1). Similar 
Table 1. Physical and physiological changes due to accelerated ageing of maize seeds

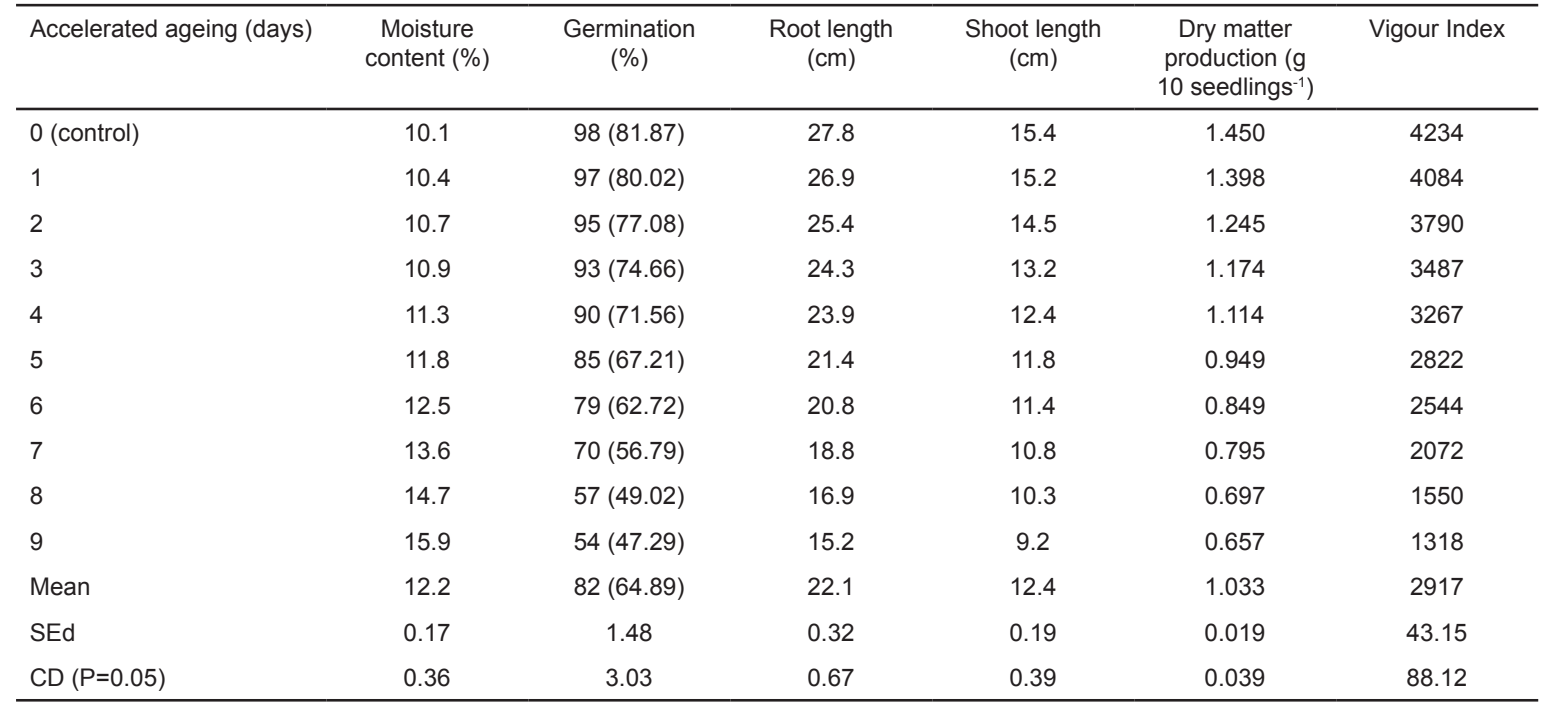

(Figures in parenthesis indicate arcsine values)

reduction in physiological parameters during ageing was also reported by Kapoor et al., (2011) in rice, Vijay et al., (2010) in soybean and Godakahriz et al., (2012) in safflower. The germination of control seeds was 98 per cent and showed declining trend with period of accelerated ageing. The germination reached IMSCS of 90 per cent on $4^{\text {th }}$ day of accelerated ageing and it was reduced further to 54 per cent on $9^{\text {th }}$ day of accelerated ageing.

Table 2. Biochemical changes due to accelerated ageing of maize seeds

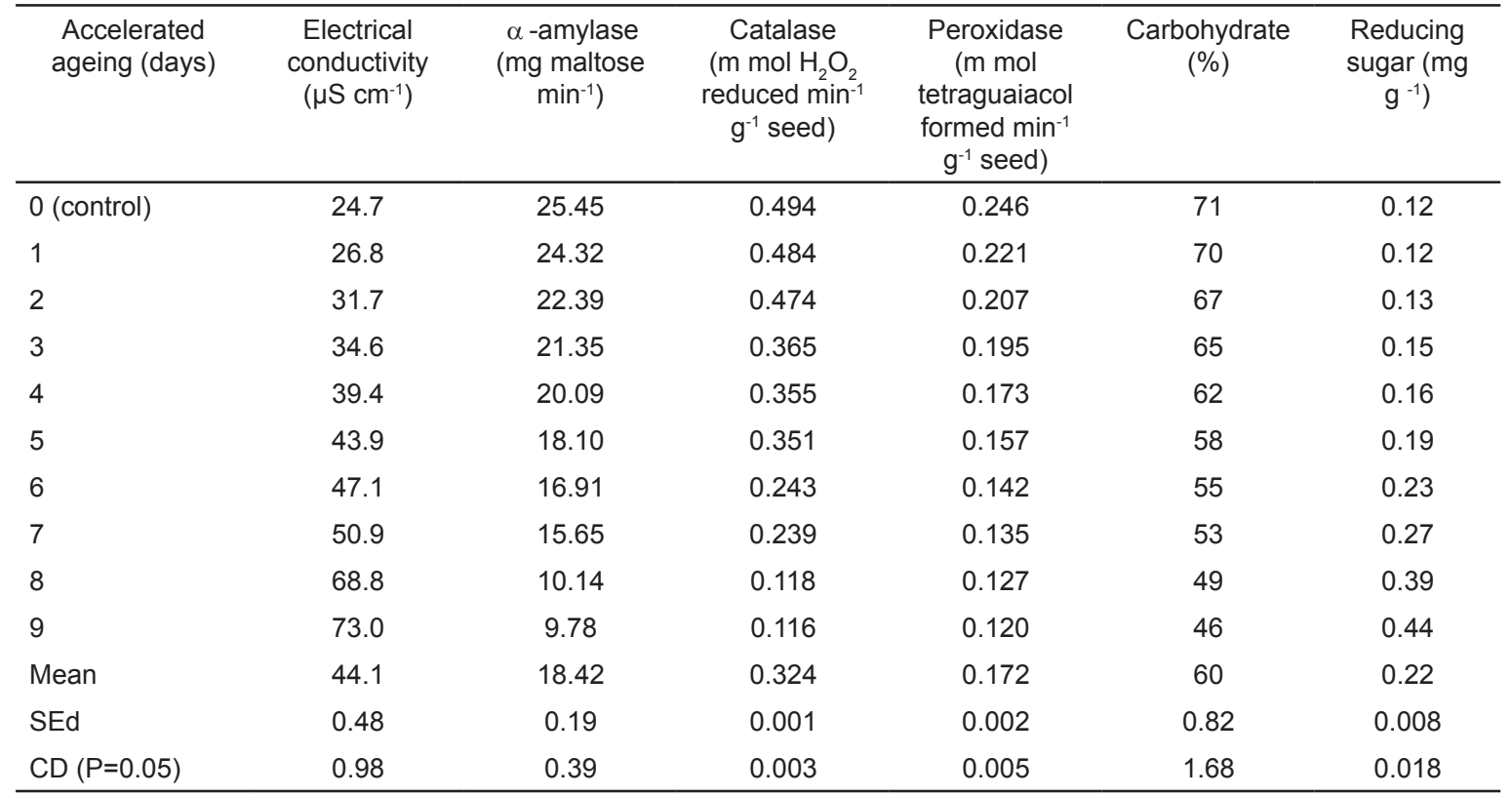

The decline in germinability during storage could be attributed to the irreversible ageing characteristics of all living biological organism causing deteriorative changes in the physical, physiological and biochemical characters of seeds (Abdul-Baki and Anderson, 1973) and Ghassemi et al. (2010) also reported that decrease in germination per cent and other indices can be related to physiological and biochemical changes during seed ageing. The accelerated ageing resulted significant reduction of root and shoot length in maize. The longest root of $27.8 \mathrm{~cm}$ and shoot of $15.4 \mathrm{~cm}$ was recorded by control seeds of maize. The root and shoot length were decreased when subjected to accelerated ageing and found to be $15.2 \mathrm{~cm}$ and $9.2 \mathrm{~cm}$, respectively on $9^{\text {th }}$ day of accelerated ageing.

In the present investigation, dry matter production and vigour index exhibited the similar trend of result as revealed in the germination and seedling length (Table 1). The maize seeds recorded dry matter production of $1.114 \mathrm{~g} 10$ seedlings $^{-1}$ and vigour index of 3267 on $4^{\text {th }}$ day of accelerated ageing Thereafter, the dry matter production and vigour index were still

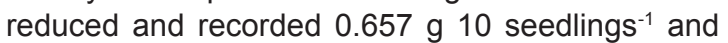


1318 , respectively on $9^{\text {th }}$ day of accelerated ageing. The control seeds recorded higher dry matter production of $1.450 \mathrm{~g} 10$ seedlings $^{-1}$ and vigour index of 4234 . The vigour index was decreased as the quality of seed became poor in course of time during ageing in maize (Basu et al., 2004). and recorded as $0.116 \mathrm{~m} \mathrm{~mol}_{2} \mathrm{O}_{2}$ reduced min $^{-1}$ $\mathrm{g}^{-1}$ seed at the end of $9^{\text {th }}$ day of accelerated ageing where control seeds recorded more catalase activity of $0.494 \mathrm{~m} \mathrm{~mol} \mathrm{H}_{2} \mathrm{O}_{2}$ reduced $\mathrm{min}^{-1} \mathrm{~g}^{-1}$ seed. (Fig. 1).

The peroxidase activity followed the similar trend of results as that of catalase activity under
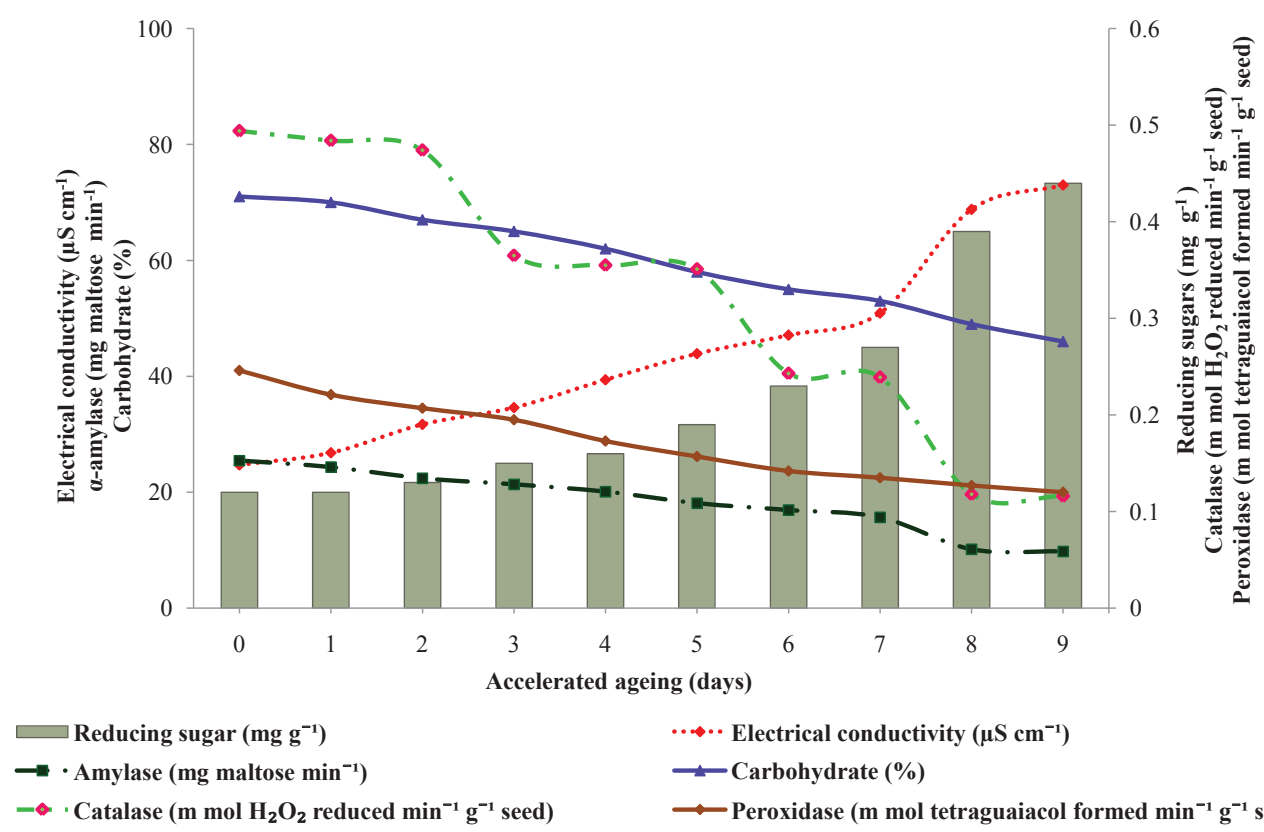

$$
\begin{aligned}
& \ldots \leftrightarrow \text { Electrical conductivity }\left(\mu \mathrm{S} \mathrm{cm}{ }^{-1}\right) \\
& \longrightarrow \text { Carbohydrate }(\%) \\
& \multimap-\text { Peroxidase }\left(\mathrm{m} \text { mol tetraguaiacol formed } \min ^{-1} \mathrm{~g}^{-1}\right. \text { seed) }
\end{aligned}
$$

\section{Fig. 1. Biochemical changes due to accelerated ageing of maize seeds}

Electrical conductivity of seed leachate is a good index of seed deterioration. Intensity of membrane damage during storage was measured by electrical conductivity of the seed leachate (Matthews and Bradnock, 1968). In the present research, the electrical conductivity of seed leachate increased with increase in period of accelerated ageing (Table 2). In maize, the electrical conductivity was less in control seeds $\left(24.7 \mu \mathrm{S} \mathrm{cm}^{-1}\right)$. In accelerated ageing, it showed an increasing trend and reached 39.4 $\mu S \mathrm{~cm}^{-1}$ on $4^{\text {th }}$ day of accelerated ageing where the germination reached IMSCS of 90 per cent. Thereafter, the electrical conductivity was drastically increased and measured as $73.0 \mu \mathrm{S} \mathrm{cm}^{-1}$ on $9^{\text {th }}$ day of accelerated ageing (Fig. 1). Gupta et al. (2005) reported that electrical conductivity increased after the seeds were subjected to accelerated ageing because of membrane deterioration and metabolic changes in the seed. Loss of seed vigour and viability is associated with deterioration of membrane properties (Priestley, 1986).

The $\alpha$-amylase activity was decreased with increasing period of storage under accelerated ageing. The $\alpha$-amylase activity was decreased from $25.45 \mathrm{mg}$ maltose $\mathrm{min}^{-1}$ at initial to $9.78 \mathrm{mg}$ maltose $\mathrm{min}^{-1}$ after 9 days of accelerated ageing (Table 2). The catalase activtity in maize seed was reduced to $0.355 \mathrm{~m} \mathrm{~mol} \mathrm{H}_{2} \mathrm{O}_{2}$ reduced $\mathrm{min}^{-1} \mathrm{~g}^{-1}$ seed on $4^{\text {th }}$ day of accelerated ageing and it was reduced further accelerated ageing (Fig. 1). The peroxidase activity in control seeds of maize was measured as 0.246 $\mathrm{m}$ mol tetraguaiacol formed $\mathrm{min}^{-1} \mathrm{~g}^{-1}$ seed. After undergoing accelerated ageing, seeds lost the activity upto $0.173 \mathrm{~m} \mathrm{~mol}$ tetraguaiacol formed $\mathrm{min}^{-1} \mathrm{~g}^{-1}$ seed and $0.120 \mathrm{~m} \mathrm{~mol}$ tetraguaiacol formed $\mathrm{min}^{-1} \mathrm{~g}^{-1}$ seed on $4^{\text {th }}$ and $9^{\text {th }}$ day of accelerated ageing, respectively (Table 2). Gidrol et al., (1989) reported that the decreased activity of catalase and peroxidase was due to accumulation of $\mathrm{H}_{2} \mathrm{O}_{2}$ and this accumulation of hydrogen peroxide itself was detrimental to seeds. Similar result was reported by Bhanuprakash et al., (2010) in bell pepper, Demirkaya et al., (2010) in onion seeds. The loss of activity of enzymes in accelerated ageing might be due to the rapid oxidative stress caused by high temperature and relative humidity.

In the present study, though the carbohydrate decreased with increase in storage period, the reducing sugars increased with increase in period of storage (Table 2). In maize, 4 days accelerated aged seeds recorded 62 per cent of carbohydrate whereas control seeds recorded 71 per cent of carbohydrate content. Reducing sugars was increased to $0.16 \mathrm{mg}$ $\mathrm{g}^{-1}$ on 4th day of accelerated ageing from $0.12 \mathrm{mg} \mathrm{g}^{-1}$ in control seeds and reached $0.44 \mathrm{mg} \mathrm{g}^{-1}$ on 9th day of accelerated ageing (Fig. 2). Bailly (2004) reported that reduction of carbohydrate and $\alpha$-amylase activity cause loss of viability in aged seeds. Bedi et al., (2006) also reported a significant increase in the 
level of reducing sugars while decrease of protein content in Brassica seeds during storage. Decrease in carbohydrate content may be due to the hydrolytic breakdown of carbohydrate into simple sugars or due to exudation by loss of cell membrane integrity (Short and Lacy, 1976).

From this study it could be concluded that while subjecting the seeds of maize single cross hybrid TNAU Maize Hybrid CO 6 to accelerated ageing, it attained minimum germination as per the IMSCS of 90 per cent on $4^{\text {th }}$ day of accelerated ageing. The root length, shoot length, dry matter production, vigour index, $\alpha$-amylase, catalase, peroxidase activity and carbohydrate content were decreased. Whereas moisture content, electrical conductivity of seed leachate and reducing sugars were increased while advancing the period of accelerated ageing.

\section{References}

Abdul-Baki, A.A. and Anderson. J.D.1973. Vigour determination of soybean seed by multiple criteria. Crop Sci., 13: 630-633.

Bailly, C. 2004. Active oxygen species and antioxidants in seed biology. Seed Sci. Res.,14(2): 93 - 107.

Basu, S., Sharma, S.P. and Dadhani, M. 2004. Storability studies on maize (Zea mays L.) parental line seeds under natural and accelerated ageing conditions. Seed Sci. \& Technol., 32: 239 - 245.

Bedi, S., Kaur, R., Sital, J.S. and Kaur, J. 2006. Artificial ageing of Brassica seeds of different maturity levels. Seed Sci. \& Technol., 34: 287 - 296.

Bhanuprakash, K.,Yogeesha, H.S. and Arun, M.N. 2010. Physiological and biochemical changes in relation to seed quality in ageing bell pepper seed. Indian J. Agri. Sci., 80(9): 777-780.

Delouche, J.C. and Baskin, C.C. 1973. Accelerated ageing techniques for predicting the relative storability seed lots. Seed Sci. \& Technol., 1(2): 427-252.
Demirkaya, M.,Dietz, K.J.and Sivritepe, H.O. 2010. Changes in Antioxidant Enzymes during Ageing of Onion Seeds. Not. Bot. Hort. Agrobot. Cluj., 38(1): 49 - 52.

Ghassemi,G.K., Khomari,S., Dalili,B., HosseinzadehMahootchy,B. and Chadordooz-Jedi, A. 2010. Effect of seed ageing on field performance of winter oil seed rape. J. Food Agric. Envir., 8(1): 175 - 178.

Gidrol, X., Serghini, H., Noubhani, A., Mocoquot, B. and Mazliak, P. 1989. Biochemical changes induced by accelerated ageing in sunflower seeds. I. Lipid peroxidation and membrane damage. Physiol. Plant., 76: 591 - 597.

Godakahriz, S.J., Rastegar, Z. and Shahverdikandi, M.A. 2012. Effect of seed ageing on safflower (Carthamus tinctorius L.) seed vigor and germination parameters. Int. Res. J. Appl. Basic Sci., 3: 445 - 449.

Gupta, V., Arya, L., Pandy, C. and Kak, A. 2005. Effect of accelerated ageing on seed vigour in pearl millet ( Pennisetum glaucum) hybrids and their parents. Indian J. Agric. Sci., 75: 346 - 347.

Kapoor N., Arya, A.,Siddiqui Mohd. Asif, Kumar, H. and Amir, A. 2011. Physiological \& Biochemical Changes During Seed Deterioration in Aged Seeds of Rice (Oryza sativa L.). Am. J. of Plant Physiol., 6(1): 28 - 35.

Mathews, S. and Bradnock, W.T. 1968. Relationship between exudation and field emergence in peas and French beans. Hort. Res., 8: 89 - 93.

Priestley, D.A. 1986. Loss of seed viability in storage. In: Seed Ageing, Cornell University press, Bhaca, London. p. 39 - 75.

Short, G.E. and Lacy, M.L. 1976. Carbohydrate exudation from pea seeds: Effect of cultivar, seed age, seed color, and temperature. Phytopathology, 66: 182 - 187.

Singh, R.K.P. and Satapathy, K.K. 2003. The zero energy cool chamber: a low cost storage structure. Journal of the North Eastern Council, 23 (3): 27 - 30.

Vijay, D.,Dadlani, M. and Vashisht, V. 2010.Comparative study of natural and accelerated ageing in soybean seeds. Crop Res., 39(1, 2\&3): 153 - 159.

http ://www.indiastat.com 